\title{
ИССЛЕДОВАНИЕ ПРОДУКТОВ КИСЛОТНОГО \\ ГИДРОЛИЗА ФАРМАЦЕВТИЧЕСКОЙ КОМПОЗИЦИИ НА ОСНОВЕ ПРИРОДНОГО ПОЛИФЕНОЛА-ГОССИПОЛА
}

\author{
А.Р. Сатаева', Е.А. Филимонова', Т.С. Серегина', ${ }^{1,2}$ И.С. Колесникова', \\ Е.В. Ивановская', В.В. Мендруль', В.А. Дятлов ${ }^{1,3}$ \\ ${ }^{1}$ Российский химико-технологический университет имени Д.И. Менделеева, факультет \\ нефтегазохимии и полимерных материалов, Москва, Россия. \\ ${ }^{2}$ ФГБУ «НМИЦ ТО им. Н.Н. Приорова», 127299, Россия, Москва, ул. Приорова, 10. \\ ${ }^{3}$ Институт тонких химических технологий имени М.В.Ломоносова, \\ 119435, Россия, Москва, Малая Пироговская ул., 1, с.5-10.
}

DOI: 10.19163/MedChemRussia2021-2021-396

E-mail:anzhesata@mail.ru

Целью настоящей работы является определение и характеристика природы веществ, выделяющихся при гидролизе полимерных лекарств прививочного типа, в которых активное вещество - госсипол - ковалентно связано с полимерным носителем.

Госсипол является токсином хлопчатника с высокой биологической активностью, которая определяет его использование в противовирусных препаратах. Однако, он негативно влияет на мужскую фертильность. Для уменьшения токсичности его связывают с полимерными носителями, при этом фармакологическая активность госсипола сохраняется. В качестве полимерных носителей активного вещества были использованы диальдегидполисахариды: диальдегидкарбоксиметилцеллюлоза (ДАКМЦ) и диальдегиддекстран (ДАД), получаемых периодатным окислением соответствующих полисахаридов по реакции Малапрада.

Для характеристики продуктов кислотного гидролиза использовались методы: 13C NMR, MALDI TOF масс-спектрометрия и GPC. В результате исследования было выяснено, что кислотный гидролиз лекарственных систем с диальдегидполисахаридами в качестве полимерных носителей ведет к образованию смеси окисленных продуктов агоссипола, которые не содержат альдегидных групп. Таким образом фармацевтическую композицию на основе госсипола, ковалентно связанного с полимерным носителем можно классифицировать как полимерное пролекарство, которое в результате гидролиза выделяет нафтохиноны с пониженной токсичностью [3].

\section{Литература}

[1]. V. G. Nesterenko, A. P. Suslov, V. A. Dyatlov, I. S. Kruppa. Gossypol polymer derivatives, methods for production thereof and pharmaceutical composition based thereon. Patent RU 2577539C2, 2016.

[2]. Дятлов В.А., Круппа И.С., Гребенева Т.А., Киреев В.В., Сокольская И.Б. Особенности ковалентного связывания госсипола с диальдегиддекстраном // Химия природных соединений, 2016. №4. 542 с.

[3]. I. S. Kruppa and V. A. Dyatlov. Acidic hydrolysis's products of glycosylated gossypol. Eur. Sci. Tech. 2015, 21-25 